\title{
Concerns about the misleading conclusions regarding estimation of the net energy value of soybean meal relative to corn using the caloric efficiency approach in pigs
}

\author{
Shuai Zhang ${ }^{*}{ }^{+}$, Zhongchao $\mathrm{Li}^{\dagger}$ and Ling Liu ${ }^{\dagger}$
}

\begin{abstract}
Apart from energy balance trials such as calorimetry, growth trials could also be used to estimate the energy values of feed ingredients with caloric efficiency as an indicator. Recent work used such methods reported greater net energy (NE) value of soybean meal (SBM) relative to corn in nursery pigs. We theoretically compared the NE values of SBM and corn according to the definition of NE and properties of the major chemical compositions in each ingredient. Meanwhile, we thoroughly examined the diet formulations and related analysis used in this work and compared this study with some peer works. We found that this study may suffer from problems with experimental design, reference citation, and data interpretation. In summary, the conclusion from the recent work that the SBM NE value may be greater than the corn NE value is likely to be erroneous.
\end{abstract}

Keywords: Caloric efficiency, Corn, Net energy, Pig, Soybean meal

\section{Main text}

Net energy (NE) is the ideal basis to express both energy requirements of pigs and energy values of feeds [1]. Therefore, it is necessary to accurately evaluate the NE value of common feed ingredients when formulating cost-efficient diets based on their combinations. Calorimetry is the traditional approach to determine the $\mathrm{NE}$ value of diets and ingredients, but it relies on specialized equipment, and is a time-consuming and laborious work. Instead, more convenient approaches such as prediction equations based on chemical components of diets and

\footnotetext{
* Correspondence: zhangshuai16@cau.edu.cn

†Shuai Zhang, Zhongchao Li and Ling Liu contributed equally to this work. State Key Laboratory of Animal Nutrition, Ministry of Agriculture and Rural Affairs Feed Industry Centre, China Agricultural University, Beijing 100193, China
}

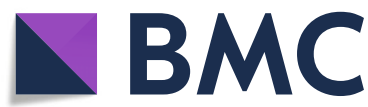

C C The Author(s). 2020 Open Access This article is licensed under a Creative Commons Attribution 4.0 International License, which permits use, sharing, adaptation, distribution and reproduction in any medium or format, as long as you give appropriate credit to the original author(s) and the source, provide a link to the Creative Commons licence, and indicate if changes were made. The images or other third party material in this article are included in the article's Creative Commons licence, unless indicated otherwise in a credit line to the material. If material is not included in the article's Creative Commons licence and your intended use is not permitted by statutory regulation or exceeds the permitted use, you will need to obtain permission directly from the copyright holder. To view a copy of this licence, visit http://creativecommons.org/licenses/by/4.0/. The Creative Commons Public Domain Dedication waiver (http://creativecommons.org/publicdomain/zero/1.0/) applies to the data made available in this article, unless otherwise stated in a credit line to the data. feed ingredients rapidly.

In the July issue of Journal of Animal Science and Biotechnology, Cemin et al. [2] presented an approach of using caloric efficiency (CE) to estimate the NE value of soybean meal (SBM) relative to corn in nursery pigs. The authors reported improved $\mathrm{CE}$ in nursery pigs consuming diets formulated based on NE values from NRC [1] when the inclusion level of dietary SBM increased from $17.5 \%$ to $40 \%$ [2]. Therefore, Cemin et al. [2] concluded that NRC [1] underestimated the NE value of SBM, which ranges between $105 \%$ to $125 \%$ of corn energy. Although respecting the authors' efforts, we have several concerns about data interpretation, experimental design, and the citation of related works, which might lead to misleading findings and conclusions. Specifically, we believe that the authors did not take the NE for lipid deposition into consideration when 
evaluating the NE value of SBM. Moreover, we found some errors in experimental diet formulation and when the authors cited some peer-reviewed works to support their inferences. Thus, the conclusion that the SBM NE value may be greater than the corn NE value is questionable.

Net energy is defined as metabolizable energy (ME) minus heat increment (HI) [1]. It has been widely accepted that the HI resulting from protein intake is much higher than that from carbohydrates and fat intake in mammals $[3,4]$. When expressed as a percentage of ME, the $\mathrm{HI}$ of feeding carbohydrate and fat to mammals vary from $6 \%$ to $15 \%$ and $4 \%$ to $10 \%$, respectively, while dietary protein can produce $30 \% \mathrm{HI}$ in mammals and birds $[3,4]$. In pigs, Le Bellego et al. [5] observed averaged $7 \mathrm{~kJ}$ decrease in heat production and averaged $3.5 \mathrm{~kJ}$ decrease in urine energy loss when replacing $1 \mathrm{~g}$ of protein with $1 \mathrm{~g}$ of starch in diets. In agreement, Noblet et al. [6] and van Milgen et al. [7] estimated the conversion efficiency of ME to NE for protein, starch, and fat to be $0.58,0.82$, and 0.90 , and $0.52,0.84$, and 0.88 , respectively. Considering the much higher crude protein content in SBM and much higher starch content in corn, the efficiency of ME utilization in SBM should be lower than that in corn. Coupled with the lower ME value in SBM [1], the NE value of SBM should be no greater than that of corn.

Net energy consumed from feed can divide into NE for maintenance $\left(\mathrm{NE}_{\mathrm{m}}\right)$, $\mathrm{NE}$ for protein deposition $\left(\mathrm{NE}_{\mathrm{p}}\right)$, and $\mathrm{NE}$ for lipid deposition $\left(\mathrm{NE}_{\mathrm{l}}\right)$ for pigs in growing-finishing stages [1]. As stated by Cemin et al. [2] in the article, the $\mathrm{CE}$ approach is more likely to be used to estimate the "productive energy" of a test ingredient, which could be on either digestible energy (DE), ME, or NE basis. The concept of CE relies on the measurement of the gain to feed ratio (G:F) without any adjustment for differences in chemical compositions of the body weight (BW) gain over the trial. This adjustment may be unnecessary if the composition of BW gain is not affected by the dietary treatments. However, in the present situation, chemical composition and especially the lipid content of BW gain must be greatly affected by the high inclusion level of
SBM or the high crude protein content of the diet. Moreover, the potential of young piglets to deposit body protein is quite high, resulting in extra body protein gain and associated BW gain under any additional supply of balanced proteins. Besides, lipid tissues of young piglets still keep growing even though at relatively low rates, but making few contributions to the BW gain [8]. As a result, the energy content of BW gain should be quite different between dietary treatments in this case, and the calculation of $\mathrm{CE}$ without any adjustment is meaningless. This limitation of the CE approach is briefly mentioned by Cemin et al. [2] in the discussion, but no subsequent consequence in the interpretation of their results.

Regarding the experimental design, the control diet and growth stages of pigs may influence the energy values of the feed ingredients estimated by the $\mathrm{CE}$ approach, as stated by Boyd and Zier-Rush [9] in their early technical report of the CE trial, who used finishing pigs and the same control diet in all experiments. However, Cemin et al. [2] used different control diets in Exp. 1 and Exp. 2, with $21 \%$ and $17.5 \%$ SBM addition, respectively, leading to different results on growth performance and energy values of ingredients. We believe the post-hoc comparison is also needed to analyze the growth performance data among the treatment groups. With such analysis, there would be no difference in G:F among diets with 21\%, 27\%, and 39\% SBM supplementation and the CE value between diets with 33\% and 39\% SBM supplementation in Exp. 1. Notwithstanding the lysine content was constant, the relatively high crude protein level in treatment groups such as $39 \%$ SBM addition could suppress the feed intake of pigs, leading to impaired G:F, which were shown in Exp. 1 but were not the situation in Exp. 2, and the authors did not give any explanation on such results. Moreover, the total rations of the ingredients in all diets are different, none of which are exactly equal to $100 \%$ (Table 1), and there are also some discrepancies between measured and calculated crude protein levels especially in Exp. 2 (Table 1), which we think may indicate erroneous SBM addition levels in actual diet formulation.

Table 1 The total rations of the ingredients and the discrepancy between calculated and measured crude protein levels in diets used by Cemin et al. [2]

\begin{tabular}{|c|c|c|c|c|c|c|}
\hline \multirow{2}{*}{$\frac{\text { Items }}{\text { Exp. } 1}$} & \multicolumn{6}{|c|}{ Treatment groups (inclusion level of soybean meal, \%) } \\
\hline & 21 & 27 & 33 & 39 & & \\
\hline Total ration, \% & 100.023 & 100.026 & 100.010 & 100.018 & & \\
\hline Calculated crude protein level, $\%$ & 19.2 & 21.3 & 23.4 & 25.6 & & \\
\hline Measured crude protein level, \% & 20 & 21.4 & 24.2 & 25.9 & & \\
\hline Exp. 2 & 17.5 & 22.0 & 26.5 & 31.0 & 35.5 & 40.0 \\
\hline Total ration, \% & 99.995 & 100.005 & 100.005 & 100.006 & 99.987 & 100.006 \\
\hline Calculated crude protein level, \% & 18.9 & 20.5 & 22.1 & 23.7 & 25.3 & 26.9 \\
\hline Measured crude protein level, \% & 17.2 & 19.2 & 20.2 & 22.7 & 23.7 & 25.6 \\
\hline
\end{tabular}


Table 2 The net energy values of corn and soybean meal from NRC [1] and from Li et al. [10] in both dry matter basis and asfed basis

\begin{tabular}{lcl}
\hline Items & Dry matter basis & As-fed basis \\
\hline Net energy value of corn, $\mathrm{kcal} / \mathrm{kg}$ & \\
From NRC [1] & 3026 & 2672 \\
From Li et al. [10] & 2978 & 2604 \\
Net energy value of soybean & meal $^{\mathrm{a}}, \mathrm{kcal} / \mathrm{kg}$ & \\
From NRC [1] & 2419 & 2148 \\
From Li et al. [10] & 2709 & 2403 \\
\hline
\end{tabular}

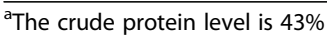

Furthermore, Cemin et al. [2] referred to the NE value of SBM measured by Li et al. [10] using indirect calorimetry to support their inferences. Nevertheless, we believe the authors made a mistake when made the comparison, because the SBM NE value of $2709 \mathrm{kcal} / \mathrm{kg}$ reported by Li et al. [10] was on a dry matter basis, while the corn $\mathrm{NE}$ value of $2672 \mathrm{kcal} / \mathrm{kg}$ listed in NRC [1] estimated by prediction equation was on an as-fed basis, meaning that we cannot compare those results directly. Although the SBM NE value measured using indirect calorimetry was greater than that using the prediction equation, it is always lower than the corn NE value when compared in the same system - either in NRC [1] or reports from Li et al. [10] (Table 2).

Finally, previous peer works also used growth trials and young piglets to validate the $\mathrm{NE}$ value of corn and SBM from NRC [1]. According to Boyd et al. [11], pigs with initial BW of $12.7 \mathrm{~kg}$ and end BW of $30.8 \mathrm{~kg}$ were fed diets formulated with corn and SBM using NE value from NRC [1], and the inclusion levels of SBM were 25.9\%, 29.3\%, 32.4\%, 35.6\% and $38.8 \%$, similar to those set in Exp. 1 conducted by Cemin et al. [2]. However, Boyd et al. [11] observed constant G:F among the five treatment groups $(0.65$, $0.66,0.65,0.65$, and $0.65, \pm 0.01, P=0.4769$ ), and indicated that the SBM NE value is 0.80 times as the corn NE value, further proved that corn could provide more $\mathrm{NE}$ value than $\mathrm{SBM}$ in growing-finishing pigs.

Overall, the study by Cemin et al. [2] suffers from some problems in experimental design, reference citation, and data interpretation, and their conclusion about the relationship between SBM NE value and corn NE value is likely to be erroneous. We believe that the $\mathrm{NE}$ values determined by the direct experimental approaches, such as indirect calorimetry, or by the prediction equations, are more reliable.

\section{Abbreviations}

BW: Body weight; CE: Caloric efficiency; DE: Digestible energy; G:F: Gain to feed ratio; HI: Heat increment; ME: Metabolizable energy; NE: Net energy; SBM: Soybean meal
Authors' contributions

SZ and ZL was the major contributor in writing the manuscript. All authors read and approved the final manuscript.

\section{Funding}

The authors reported no funding received for this work.

\section{Availability of data and materials \\ Not applicable.}

Ethics approval and consent to participate

Not applicable.

Consent for publication

Not applicable.

\section{Competing interests}

The authors declare no competing interests.

Received: 28 September 2020 Accepted: 13 October 2020

Published online: 24 November 2020

\section{References}

1. NRC. Nutrient requirements of swine. 11th ed. Washington: Natl. Acad. Press; 2012.

2. Cemin HS, Williams HE, Tokach MD, Dritz SS, Woodworth JC, De Rouchey $J M$, et al. Estimate of the energy value of soybean meal relative to corn based on growth performance of nursery pigs. J Animal Sci Biotechnol. 2020;11:70.

3. Hrody. Bioenergetics and growth. New York: Reinhold Publishing Co; 1945. Reprinted by Hafner Press; 1974.

4. Smith RR, Rumsey GL, Scott ML. Heat increment associated with dietary protein, fat, carbohydrate and complete diets in salmonids: comparative energetic efficiency. J Nutr. 1978;108(6):1025-32.

5. Le Bellego L, van Milgen J, Dubois S, Noblet J. Energy utilization of low protein diets in growing pigs. J Anim Sci. 2001;79:1259-71.

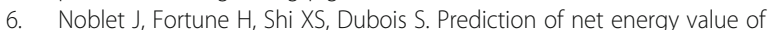
feeds for growing pigs. J Anim Sci. 1994;72:344-54.

7. van Milgen J, Noblet J, Dubois S. Energetic efficiency of starch, protein and lipid utilization in growing pigs. J Nutr. 2001;131:1309-18.

8. Kyriazakis I, Whittemore CT. Whittemore's science and practice of pig production, 3rd ed. 2007. Oxford: Blackwell Publishing Ltd; 2006.

9. Boyd RD, Zier-Rush CE. Practical method for calibrating ingredient net energy estimates for growing pigs: growth assay calibration of wheat MIDD S; application of the 'Snyder Growth Assay' for ingredient NE calibration. The Hanor Company. 2008; Hanor Technical Memo H 2008-10 TEK. doi: https://doi.org/10.13140/RG.2.2.24483.25125. Accessed 20 Nov 2020.

10. Li Z, Li Y, Lv Z, Liu H, Zhao J, Noblet J, et al. Net energy of corn, soybean meal and rapeseed meal in growing pigs. J Anim Sci Biotechnol. 2017:8:44.

11. Boyd RD, Zier-Rush CE, Smith S, Shirley R, Touchette KJ. Growth validation of net energy estimates for soybean meal and fat (CWG) using 12 to $30 \mathrm{~kg}$ pigs, vol. 136. Des Moines: ADSA-ASAS Midwest Meeting; 2014.

Ready to submit your research? Choose BMC and benefit from:

- fast, convenient online submission

- thorough peer review by experienced researchers in your field

- rapid publication on acceptance

- support for research data, including large and complex data types

- gold Open Access which fosters wider collaboration and increased citations

- maximum visibility for your research: over $100 \mathrm{M}$ website views per year

At BMC, research is always in progress.

Learn more biomedcentral.com/submissions 